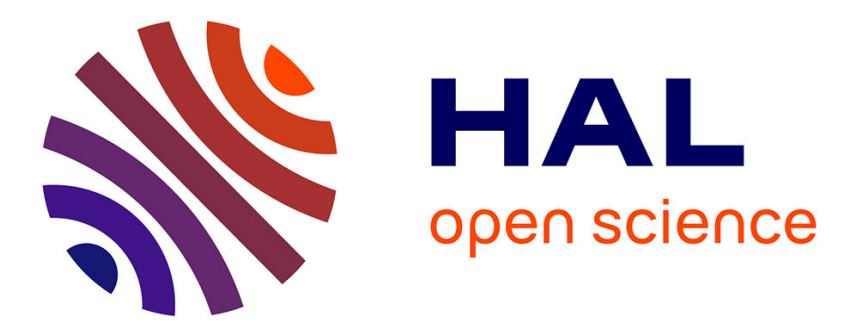

\title{
4H-pyranylidene-based small push-pull chromophores: Synthesis, structure, electronic properties and photovoltaic evaluation
}

Víctor Tejeda-Orusco, Martin Blais, Clément Cabanetos, Philippe Blanchard, Raquel Andreu, Santiago Franco, Jesús Orduna, Beatriz Diosdado

\section{To cite this version:}

Víctor Tejeda-Orusco, Martin Blais, Clément Cabanetos, Philippe Blanchard, Raquel Andreu, et al.. $4 \mathrm{H}$-pyranylidene-based small push-pull chromophores: Synthesis, structure, electronic properties and photovoltaic evaluation. Dyes and Pigments, 2020, 178, pp.108357. 10.1016/j.dyepig.2020.108357. hal-02888754v2

\section{HAL Id: hal-02888754 \\ https://hal.science/hal-02888754v2}

Submitted on 21 Oct 2021

HAL is a multi-disciplinary open access archive for the deposit and dissemination of scientific research documents, whether they are published or not. The documents may come from teaching and research institutions in France or abroad, or from public or private research centers.
L'archive ouverte pluridisciplinaire HAL, est destinée au dépôt et à la diffusion de documents scientifiques de niveau recherche, publiés ou non, émanant des établissements d'enseignement et de recherche français ou étrangers, des laboratoires publics ou privés. 


\title{
4H-pyranylidene-based small push-pull chromophores: synthesis, structure, electronic properties and photovoltaic evaluation.
}

\author{
Víctor Tejeda-Orusco, ${ }^{\mathrm{a}}$ Martin Blais, ${ }^{\mathrm{b}}$ Clément Cabanetos, ${ }^{\mathrm{b}}$ Philippe Blanchard, ${ }^{\mathrm{b}, *}$ Raquel \\ Andreu,,${ }^{\mathrm{a},}$ Santiago Franco, ${ }^{\mathrm{a}}$ Jesús Orduna, ${ }^{\mathrm{a}}$ Beatriz E. Diosdado. ${ }^{\mathrm{a}}$ \\ a Departamento de Química Orgánica, ICMA, Universidad de Zaragoza-CSIC, 50009 \\ Zaragoza, Spain. \\ b MOLTECH-Anjou, UMR 6200, UNIV Angers, CNRS, SFR Matrix, 2 bd Lavoisier, \\ 49045 ANGERS Cedex, France.
}

Corresponding author: randreu@unizar.es; philippe.blanchard@univ-angers.fr.

Dedicated to Dr. Gemma Ceprià for her friendship, enthusiasm and support while she was with us.

\begin{abstract}
The synthesis and electrochemical and optical characterizations of four new $4 \mathrm{H}$ pyranylidene-based push-pull molecules are reported herein as well as their evaluation as donor materials for organic photovoltaics. Studied systems exhibit good absorption properties and appropriate LUMO levels for a photoinduced electron transfer to $\mathrm{C}_{60}$. Bilayer organic solar cells fabricated from these new donors and $\mathrm{C}_{60}$ as acceptor gave photocurrent however with low power conversion efficiencies. As shown by X-ray diffraction and theoretical calculations, titled molecules present a twisted structure which may prevent the formation of suitable $\pi-\pi$ contacts between adjacent molecules hence explaining their low photovoltaic performance.
\end{abstract}


Keywords: Push-pull systems, 4H-pyranylidene, small conjugated molecules, organic photovoltaics.

\section{Introduction}

Small $\pi$-conjugated molecules alternating electron-donating (D) and electron-accepting (A) units with various combinations are of considerable interest as active donor materials[1] as well as non-fullerene acceptors[2] for organic photovoltaics (OPV). In these structures, the most commonly used electron donor blocks include $e$. $g$. nitrogen derivatives based on arylamine[3] or carbazole, and thiophene-based conjugated systems derived from oligothiophenes or fused 3,4-dihydro-2H-cyclopenta[2,1-b:3,4- $\left.b^{\prime}\right]$ dithiophene, silolo[3,2$\left.b: 4,5-b^{\prime}\right]$ dithiophene, $\quad$ benzo[1,2- $\left.b ; 4,5-b^{\prime}\right]$ dithiophene $\quad$ and $\quad$ s-indaceno[1,2- $b: 5,6-$ $b^{\prime}$ ]dithiophene.[1,2]

On the other hand, the oxygen-containing $\gamma$-pyranylidene unit represents a versatile building block that has been extensively introduced in conjugated systems for applications in the fields of photonics and organic electronics. Its proaromatic character[4] promotes an intramolecular charge transfer (ICT) process in D-A systems through a gain in aromaticity. Interestingly, condensation between pyran-4-one and various $\mathrm{CH}_{2}$-activated compounds such as malononitrile, dicyanovinylindan-3-one, indanedione or (thio)barbituric acid is very often used to prepare electron-withdrawing $\gamma$-pyranylidene blocks[5] whereas less electrondonating $\gamma$-pyranylidene blocks have been reported.[4] Thus, the synthetic versatility provided by this building block allowed the preparation and characterization of a variety of structures, affording materials with interesting properties, such as second-order nonlinear optical (NLO) activity[4,6] or two photon absorption,[7] organic light-emitting diodes,[8] good performance as dyes in Dye Sensitized Solar Cells (DSSCs)[9] or for the aggregation-induced emission enhancement phenomena.[10] 
Regarding the field of small molecules acting as donor materials for organic solar cells (OSCs), the $4 H$-pyranylidene unit has been used as $\pi$-spacer in combination with acceptor groups, such as dicyanovinyl (DCV)[11] or (thio)barbituric acids.[12] However, to the best of our knowledge, the $\gamma$-pyranylidene moiety has never been used as electron-donating group D in small conjugated D-A molecules for photovoltaic application, although an heteroquinoid merocyanine dye derived from 2,6-diphenyl-4H-pyranylidene has been recently considered. [13] It is worth noting that a parent dipyran-based ladder-type building block has been recently used as central donating group D in A-D-A conjugated molecules for efficient nonfullerene acceptors in OPV.[14]

On the other hand, the system 2,2',6,6'-tetraphenyldipyranylidene has been used as holetransporting material for hybride perovskite solar cells,[15] and as an efficient hole-collecting interfacial layer in organic solar cells based on poly(3-hexylthiophene):phenyl- $\mathrm{C}_{61}$-butyric acid methylester (P3HT:PCBM).[16]

Within this context, and having in mind our experience with the synthesis and characterization of push-pull systems featuring the $4 H$-pyranylidene fragment for optical applications and DSSCs,[4;6a,c,d;9b,c,e] we present here the synthesis and the electronic properties of four novel small push-pull conjugated molecules. (Fig. 1) In these systems, the exocyclic $\mathrm{C}=\mathrm{C}$ double bond of a $4 \mathrm{H}$-pyranylidene proaromatic electron-donating unit is functionalized by two thiophene rings end-capped at their 5-positions by one (compounds $\mathbf{1}$ ) or two identical (compounds 2) electron-withdrawing unit(s), namely a DCV (derivatives a) or a 4-phenyl-2-oxo-2,5-dihydrofuran-3-carbonitrile (derivatives b) unit.

The latter has never been used before in the field of OPV, but gave rise to the preparation of chromophores with an effective polarization and upgraded second-order NLO responses.[17] 
The electronic properties of these compounds are discussed with emphasis on structureproperty relationships with the help of theoretical calculations. Moreover, the potential of these derivatives as donor materials in OPV is reported throughout this article.

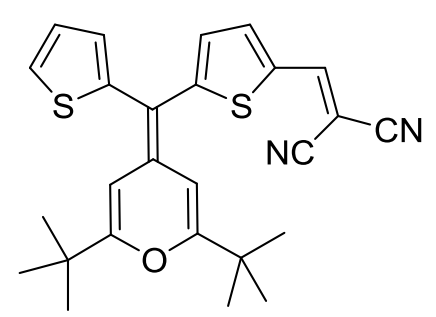

$1 \mathbf{a}$<smiles>CC(C)(C)C1=CC(=C(c2ccc(C=C(C#N)C#N)s2)c2ccc(C=C(C#N)C#N)s2)C=C(C(C)(C)C)O1</smiles>

$2 a$<smiles>CC(C)(C)C1=CC(=C(c2cccs2)c2ccc(C=C3OC(=O)C(C#N)=C3c3ccccc3)s2)C=C(C(C)(C)C)O1</smiles>

$1 \mathrm{~b}$<smiles>CC(C)(C)C1=CC(=C(c2ccc(C=C3OC(=O)C(C#N)=C3c3ccccc3)s2)c2ccc(C=C3OC(=O)C(C#N)=C3c3ccccc3)s2)C=C(C(C)(C)C)O1</smiles>

2b

Fig. 1. Molecular structures of the target compounds.

\section{Results and discussion}

\subsection{Synthesis}

Target D- $\pi$-A systems $\mathbf{1 a - b}$ and $\mathbf{2 a - b}$ were prepared by Knœvenagel condensation between the $4 H$-pyranylidene-containing aldehydes $\mathbf{1 - C H O}[9 \mathrm{e}]$ or 2-CHO[9e] and malononitrile (3) or 4-phenyl-2-oxo-2,5-dihydrofuran-3-carbonitrile (4)[18] (Scheme 1). The conditions used for the condensation were in each case adapted to the nature of the $\mathrm{CH}_{2}$-activated reagent. While basic conditions $\left(\mathrm{Al}_{2} \mathrm{O}_{3}\right)$ were used for the reaction with malononitrile,[19] the condensation with 4-phenyl-2-oxo-2,5-dihydrofuran-3-carbonitrile (4) was directly performed in refluxing ethanol.[17] Yields ranged from 26 to $86 \%$. 

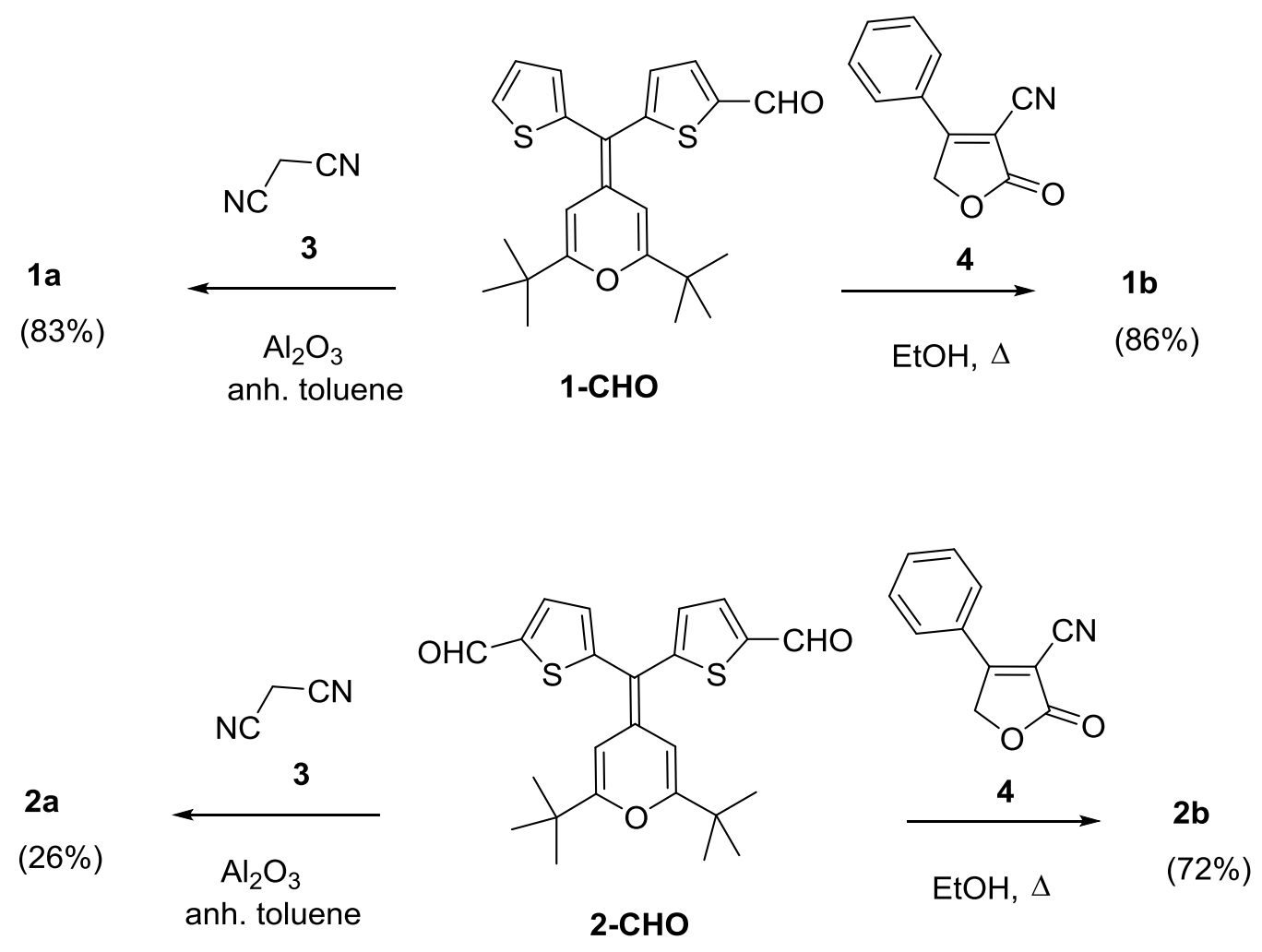

Scheme 1: Synthesis of $4 H$-pyranylidene-based push-pull molecules.

\subsection{Structural characterization by X-ray diffraction.}

Single crystals of compound 1a obtained by slow diffusion of hexane into a solution of the corresponding donor in $\mathrm{CH}_{2} \mathrm{Cl}_{2}$ at room temperature, were analysed by $\mathrm{X}$-ray diffraction. The $\mathrm{X}$-ray molecular structure of $\mathbf{1 a}$ is represented in Fig. 2. In order to distinguish the two thiophene rings of 1a for the discussion, they will be named as S1 and S2 following the labelling shown in Fig. 2. Thiophene S1 is disordered (77\% S1C and 23\% C1S) due to the free rotation around the $\mathrm{C} 14-\mathrm{C} 15$ single bond. 


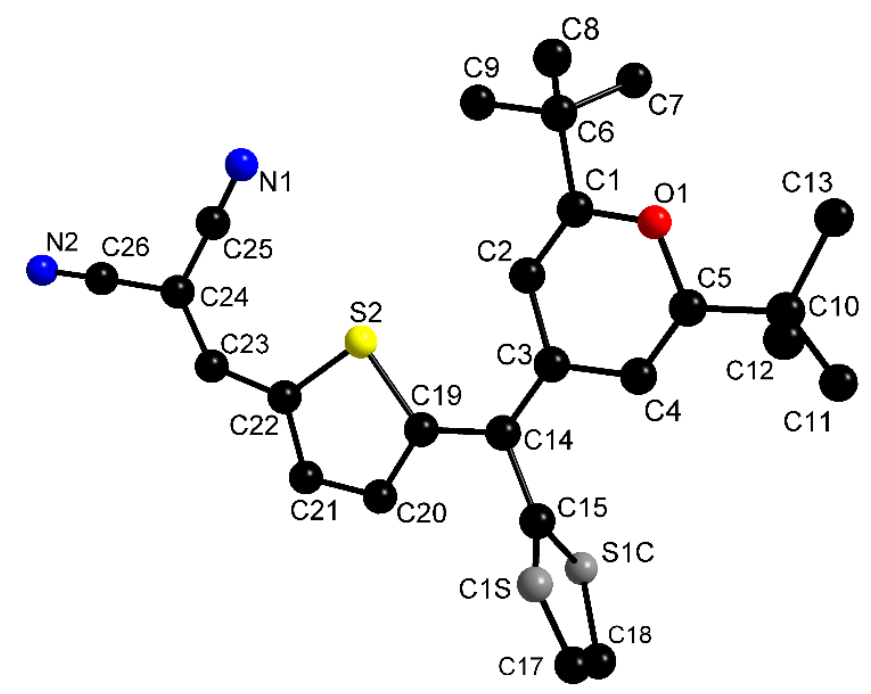

Fig. 2. Molecular structure of compound 1a.

The DCV group of compound 1a adopts a cis conformation (along the C22-C23 bond) relative to the sulfur atom of the vicinal thiophene $S 2$, as previously found in its analogous compound without the additional thiophene ring (S1) (Compound 5, Fig. $3(\mathrm{R}=\mathrm{H})$ ), [20] and in other compounds featuring thiophene moieties end-capped with DCV groups.[21]

The extended conjugated $\pi$-system in 1a, involving the pyran, thiophene S2 and DCV units, is essentially planar, with an angle of $6.8^{\circ}$ between the mean planes of the pyran ring and that of the thiophene $\mathrm{S} 2$, and an angle of $9.6^{\circ}$ between the planes of thiophene S2 and the DCV unit. However, in contrast to the completely planar conjugated pathway shown by the X-ray structure of compound $\mathbf{5}$, the presence of the additional thiophene S1 slightly distorts the planarity of the extended $\pi$-system.

In addition, the $\mathrm{S} 1$ thiophene ring is out of the plane of the aforementioned planar $\pi$-system, the value of the dihedral angle $\mathrm{C} 3-\mathrm{C} 14-\mathrm{C} 15-\mathrm{S} 1 \mathrm{C}$ being of $100.7^{\circ}$. Thus, thiophene ring S1 is almost perpendicular to the conjugated system (Fig. S-12), with angles of $77.2^{\circ}$ between the mean planes of thiophene $\mathrm{S} 1$ and the pyran rings, and $82.7^{\circ}$ between the two thiophene moieties S1 and S2. 
Comparison of the bond lengths of compounds 1a and $\mathbf{5}$ together with the standard[22] $\mathrm{C}=\mathrm{C}$ and $\mathrm{C}-\mathrm{C}$ bonds in thiophenes derivatives and 2,2',6,6'-tetraphenylbipyranylidene[23] (a 4H-pyranylidene derivative taken as model quinoidal compound) (Fig. 3), allows us to highlight the following features about the ICT in these compounds: (i) comparison of the standard $\mathrm{C}=\mathrm{C}$ and $\mathrm{C}-\mathrm{C}$ bonds in an unsubstituted aromatic thiophene with data for systems $\mathbf{1 a}$ and 5 reveals the $\pi$-electron delocalization along the thiophene ring in these compounds; (ii) the $\mathrm{C}-\mathrm{O}$ bond is shorter in compound $\mathbf{1 a}$ than in $\mathbf{5}$, leading to a more zwitterionic contribution to the ground state in 1a; (iii) the $\mathrm{C}_{4}-\mathrm{C}_{\text {exo }}$ bond for compound $\mathbf{5}$ is even shorter than the $\mathrm{C}_{4-}$ $\mathrm{C}_{\text {exo }}$ one in the model quinoidal derivative. The two later features reveals that whereas for compound $\mathbf{5}$, the thiophene moiety seems to be the main donor involved in the ICT process towards the acceptor unit,[20] the transfer of charge arises from the pyran ring for compound 1a, in agreement with other $4 H$-pyranylidene- $\pi-$ A systems previously reported.[4,24]

Molecules are stacked along the $c$ axis, with a head-to-tail arrangement (see Fig. S-13 to S15), as generally observed for strongly dipolar compounds.[25] Distance between the planes of two neighbouring molecules is close to $9 \AA$, likely due to the presence of the cumbersome thiophene S1 rings, almost perpendicular to the conjugated $\pi$-pathway. This fact prevents suitable $\pi-\pi$ stacking interactions.

CCDC-1962297 contains the supplementary crystallographic data for this article. These data can be obtained free of charge from The Cambridge Crystallographic Data Centre. 

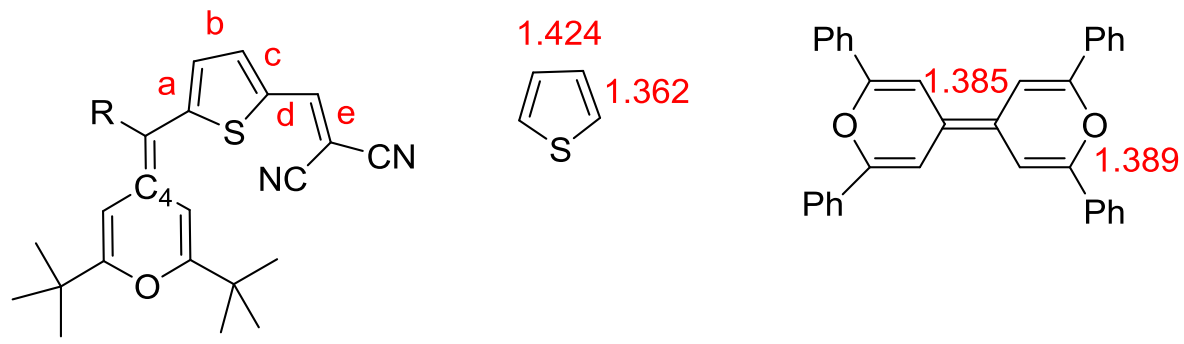

\begin{tabular}{lcccccccc}
$\mathbf{R}$ & Compd & $\begin{array}{c}\mathrm{C}-\mathrm{O} \\
\text { (average) }\end{array}$ & $\mathrm{C}_{4}-\mathrm{C}_{\text {exo }}$ & $\mathrm{a}$ & $\mathrm{b}$ & $\mathrm{c}$ & $\mathrm{d}$ & $\mathrm{e}$ \\
\hline & $\mathbf{1 a}$ & 1.367 & 1.382 & 1.392 & 1.383 & 1.382 & 1.409 & 1.365 \\
$\mathrm{H}$ & $\mathbf{5}$ & 1.378 & 1.357 & 1.389 & 1.388 & 1.404 & 1.413 & 1.337
\end{tabular}

All bond lenghts in $\AA$

Fig. 3. Selected bond lengths $(\AA)$ for compounds 1a, 5, thiophene and 2,2',6,6'tetraphenylbipyranylidene.

\subsection{Optical properties}

The optical properties of titled compounds have been investigated by UV/Vis spectroscopy in dichloromethane solution. Table 1 lists the main optical properties of compounds $\mathbf{1 a - b}$ and $\mathbf{2 a - b , ~ t o g e t h e r ~ w i t h ~ t h o s e ~ o f ~ r e f e r e n c e ~ c o m p o u n d ~ 5 [ 2 0 ] ~ f o r ~ c o m p a r i s o n . ~}$

Table 1: UV-vis absorption data in $\mathrm{CH}_{2} \mathrm{Cl}_{2}$.

\begin{tabular}{|l|c|c|}
\hline Compound & $\lambda_{\mathrm{abs}}, \mathrm{nm}$ & $\varepsilon, \mathrm{M}^{-1} \mathrm{~cm}^{-1}$ \\
\hline 1a & 562 & 35811 \\
\hline $\mathbf{1 b}$ & 645 & 38406 \\
\hline $\mathbf{2 a}$ & 547 & 33026 \\
\hline $\mathbf{2 b}$ & 626 & 40131 \\
\hline $\mathbf{5}[18]$ & 568 & 46400 \\
\hline
\end{tabular}


Albeit small, all titled chromophores exhibit intense and broad bands in the visible region (Fig. 4), which can be assigned to an ICT process between the donor and the acceptor moieties.

Comparison of optical properties of compounds that only differ in the acceptor group shows a significant bathochromic shift for $\mathbf{b}$ derivatives, in agreement with the more $\pi$-extended system and the higher electron-withdrawing ability of the furanone moiety. Moreover, b systems present higher molar extinction coefficients $(\varepsilon)$ than those of DCV analogues a.

Compared to 5, the additional thiophene moiety, nearly orthogonal to the extended $\pi$-system (see section 2.2), leads to a slight hypsochromic shift for 1a. This point might be a consequence of the slight deviation from planarity (see section 2.2) imposed to the conjugated system by the additional thiophene ring, in contrast to the completely planar $\pi$ system shown by compound 5.[20]

The introduction of a second acceptor group at the terminal alpha position of the twisted thiophene ring in molecules 2 induces a further blue-shifted absorptions when compared to their analogues $\mathbf{1}$.

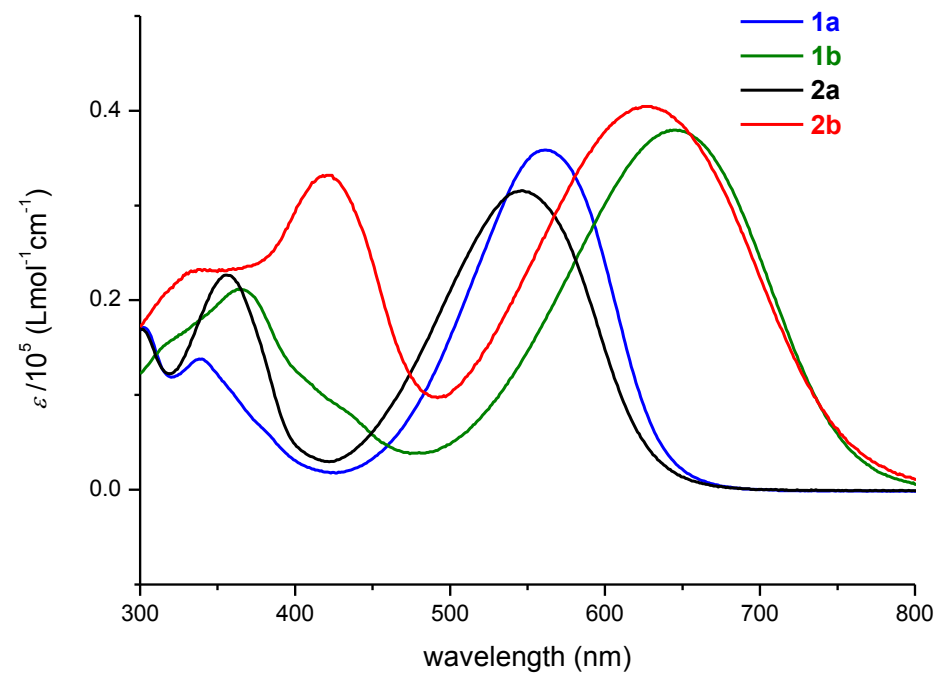


Fig. 4. Absorption spectra of compounds in $\mathrm{CH}_{2} \mathrm{Cl}_{2}$ : $\mathbf{1 a}$ (blue), $\mathbf{1 b}$ (green), $\mathbf{2 a}$ (black), $\mathbf{2 b}$ (red).

\subsection{Electrochemical study}

The electrochemical properties of the four molecules have been analyzed by cyclic voltammetry in dichloromethane solution in the presence of $\mathrm{Bu}_{4} \mathrm{NPF}_{6}$ as the supporting electrolyte. Data are summarized in Table 2, together with those of reference compound $\mathbf{5}$ in the same conditions.

Table 2: Electrochemical data ${ }^{a}$ and $E_{\mathrm{HOMO}}$ and $E_{\mathrm{LUMO}}$ values theoretically calculated. ${ }^{b}$

\begin{tabular}{|l|c|c|c|c|c|}
\hline Compound & $E_{\mathrm{ox} 1}{ }^{1 / 2}(\mathrm{~V})$ & $E_{\mathrm{ox} 2}{ }^{1 / 2}(\mathrm{~V})$ & $E_{\mathrm{red}}(\mathrm{V})$ & $E_{\mathrm{HOMO}}(\mathrm{eV})$ & $E_{\mathrm{LUMO}}(\mathrm{eV})$ \\
\hline $\mathbf{1 a}$ & +0.73 & +1.04 & -1.18 & -6.46 & -2.27 \\
\hline $\mathbf{1 b}$ & +0.64 & +0.92 & -0.87 & -6.25 & -2.56 \\
\hline $\mathbf{2 a}$ & +0.88 & +1.29 & -1.16 & -6.56 & -2.31 \\
\hline $\mathbf{2 b}$ & +0.68 & +0.95 & -0.82 & -6.30 & -2.58 \\
\hline $\mathbf{5}[18]$ & $+0.82^{c}$ & & -1.23 & -6.42 & -2.25 \\
\hline
\end{tabular}

${ }^{a} 5 \times 10^{-4} \mathrm{M}$ in $\mathrm{CH}_{2} \mathrm{Cl}_{2}$ versus $\mathrm{Ag} / \mathrm{AgCl}(3 \mathrm{M} \mathrm{KCl})$, glassy carbon working electrode, $\mathrm{Pt}$ counter electrode, $20^{\circ} \mathrm{C}, 0.1 \mathrm{M} \mathrm{NBu}_{4} \mathrm{PF}_{6}, 100 \mathrm{mV} \mathrm{s}^{-1}$ scan rate. For these conditions: $E_{\text {ox }}{ }^{1 / 2}$ ferrocene $=+0.45$ V. ${ }^{b}$ Calculated at the CPCM-M06-2X/6-311+G(2d,p)//M06-2X/6-31G* level in $\mathrm{CH}_{2} \mathrm{Cl}_{2} .{ }^{c}$ Irreversible process.

The cyclic voltammograms (CVs) of compounds $\mathbf{1}$ and $\mathbf{2}$ show one irreversible reduction peak (involving the acceptor unit) and two reversible oxidation waves (Fig. 5 and S-10). It is important to note that compared to compound $\mathbf{5}$, the introduction of a thiophene ring in the exocyclic carbon of the $4 H$-pyranylidene fragment changes appreciably the oxidation behavior of titled compounds $\mathbf{1}$ and $\mathbf{2}$ (Table 2).

In this way, compound 5[20] displays (See Fig. S-9) a single irreversible oxidation peak at $0.82 \mathrm{~V}$ corresponding to the formation of the pyrylium radical cation followed by a rapid dimerization reaction leading to a dipyrylium salt. The reverse scan exhibits an irreversible 
cathodic peak at $0.46 \mathrm{~V}$, assigned to the reduction of the dipyrylium cation leading to 5 after a $\mathrm{C}-\mathrm{C}$ cleavage reaction. Both observations are consistent with results previously described for other methylenepyran derivatives.[9d,26]

For compounds 1a-b and $\mathbf{2 a - b}$, with an additional thienyl ring in the ethylene bridge, two reversible oxidation processes are observed, which can be ascribed to the successive monoelectronic oxidations of the pyranylidene moiety, as previously observed for push-pull platinum complexes with this electron-donating group[27] and for their starting organic material.

Compounds 1a-b with one acceptor unit, show lower $E_{\mathrm{ox}}$ values than for the corresponding analogues $\mathbf{2 a - b}$ with two acceptor units; this fact may be related to the better planarization of the $\pi$-conjugated system of mono-functionalized compounds $\mathbf{1}$, leading to a better stabilization of the radical-cation. This feature is more remarkable for derivatives a than for compounds b. On the other hand, this structural variation does not seem to have such an impact on $\left|E_{\text {red }}\right|$ values for DCV derivatives whereas for $\mathbf{b}$ series, a lower $\left|E_{\text {red }}\right|$ is found in compound $\mathbf{2 b}$.

For a given series (1 $\mathbf{1}$ or $\mathbf{2})$, there is a shift of the $\left|E_{\text {red }}\right|$ values towards less cathodic potentials when changing the acceptor from dicyanomethylene to the $2(5 H)$-furanone group, indicating the superior electron-accepting ability of the latter. UV-vis study also supports the comparatively weaker electron-withdrawing ability of the DCV group. On the other hand, there is a shift of the $E_{\mathrm{ox}}$ values (first and second potentials) towards less anodic potentials when passing from dicyanomethylene (a) to $2(5 H)$-furanone derivatives (b), this can be explained by the more $\pi$-extended furanone system more prone to stabilize the radical cation and dicationic species (Fig. 5). In addition, the potential difference value $\Delta E_{\mathrm{ox}}{ }^{1 / 2}(1-2)=$ $E_{\mathrm{ox}}{ }^{1 / 2}(2)-E_{\mathrm{ox}}{ }^{1 / 2}(1)$ is lower for derivatives $\mathbf{b}$, in agreement with less coulombic repulsion in the dicationic state due the more $\pi$-extended furanone derivatives $\mathbf{b}$. 


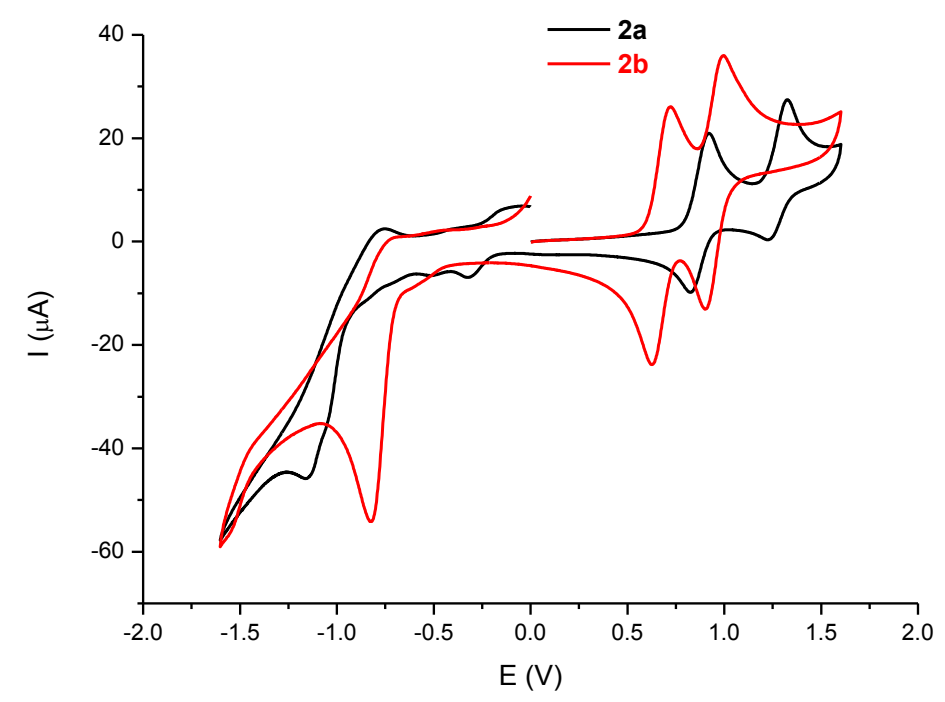

Fig. 5: Cyclic voltammograms of compounds $\mathbf{2 a}$ (black) and $\mathbf{2 b}$ (red). For conditions, see Table 2.

\subsection{Theoretical calculations}

In order to get further insight into the geometry and electronic properties of the studied compounds, theoretical calculations using DFT (Density Functional Theory) and the CPCM (Conductor-like Polarizable Continuum Model) solvation method were performed.

Concerning the geometry of the studied dyes, (see Fig. S-16 to S-19) calculations show that the push-pull $\pi$-system of compounds $\mathbf{1}$ is almost planar. Taking compound $\mathbf{1 a}$ as model, it can be inferred that in the calculated structure, the conjugated $\pi$-pathway deviates more from planarity than in the X-ray structure. Thus, the calculated angle between the pyranylidene unit and the thiophene ring is $18^{\circ}$. Indeed, the additional thiophene ring appears also almost perpendicular to the push-pull conjugated system.

The distortion from planarity shown by theoretical calculations (and also by X-Ray diffraction for 1a) is in agreement with that found in related $4 H$-pyranylidene derivatives recently described as dyes for DSSCs.[9e] In that case, the twisted structures prevent the 
formation of aggregates which is beneficial for DSSCs and, therefore, give rise to an increase of the efficiency of the corresponding cells.

Compounds $\mathbf{2}$ have a C2 symmetry axis and taking compound $\mathbf{2 a}$ as model, the angle found between the main planes of the pyranylidene ring and either the two vicinal thiophene rings is $45^{\circ}$

Calculations at the ground state geometry allowed to obtain orbital energies (data are collected in Table 2) and topologies. The calculated values of the HOMO and LUMO levels are consistent with electrochemical results (Table 2). Thus, $E_{\mathrm{HOMO}}\left(E_{\mathrm{LUMO}}\right)$ values for systems b are higher (lower) than those encountered for their a analogues, in agreement with the less anodic potentials measured for $\mathbf{b}$ derivatives and with the superior electron-withdrawing ability of the furanone group. On the other hand, passing from compounds $\mathbf{1}$ to $\mathbf{2}$ leads to a decrease in both the HOMO and LUMO levels.

Moreover, according to the calculations, electron densities related to frontier orbitals (see topologies for compounds 1a and 2a in Fig. 6 and for the rest in the Supporting Information) are mainly localized on the $4 H$-pyranylidene unit and the thienyl ring for the HOMO, and on the thiophene-acceptor block in the case of the LUMO. For systems 1, the additional thiophene unit does not have a significant contribution neither to the HOMO nor to the LUMO.

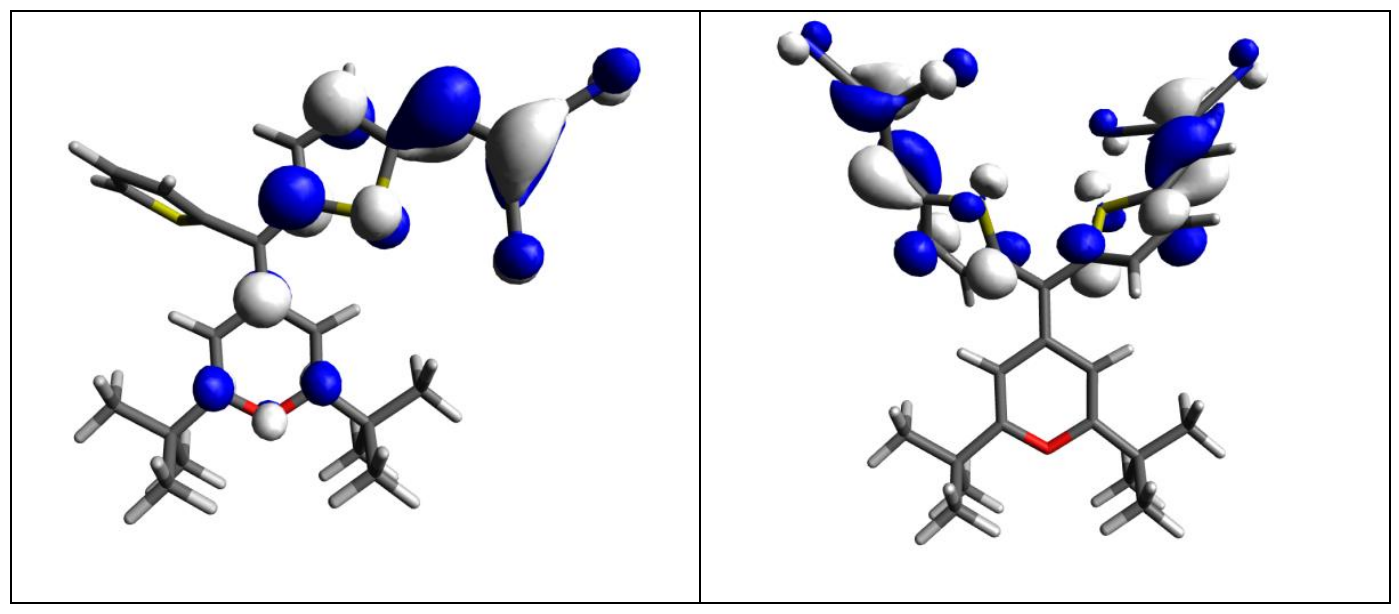




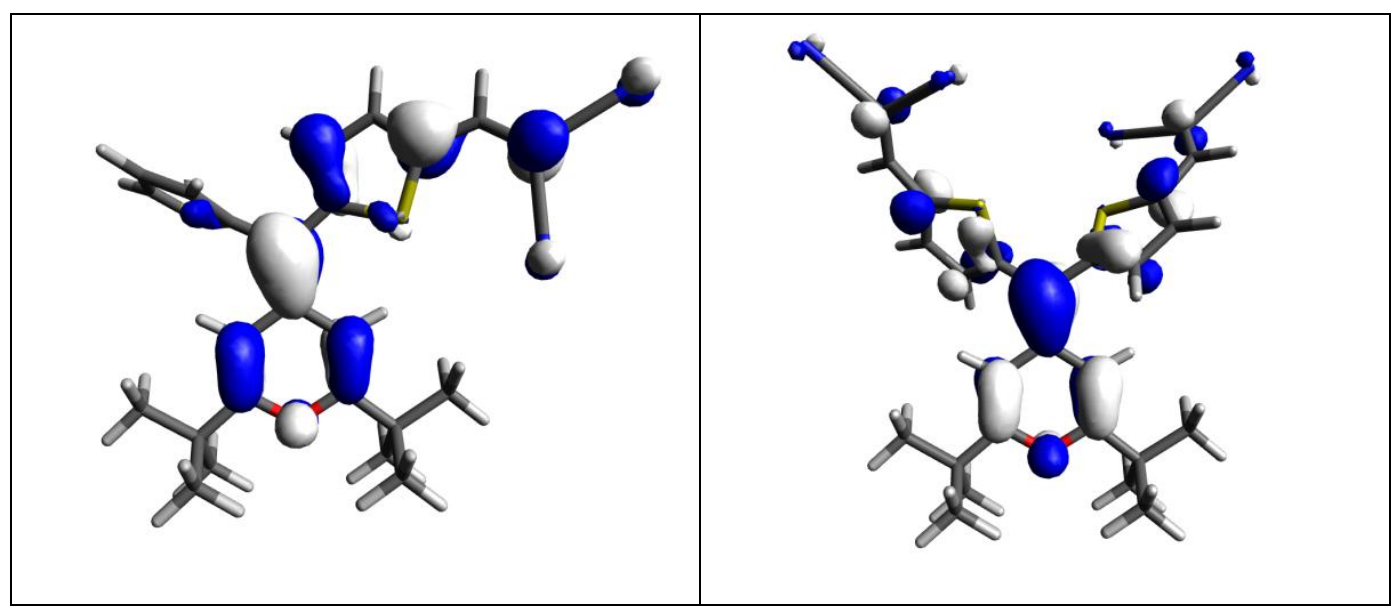

Fig. 6. Illustration of the HOMO (bottom) and LUMO (top) of compounds 1a (left) and 2a (right).

Moreover, according to time dependent DFT calculations (TD-DFT), the first excited state is mainly associated to a one electron HOMO to LUMO transition, and there is a large HOMO-LUMO spatial overlap that accounts for the high molar extinction coefficients $(\varepsilon)$ (Table 1).

A more complex picture is obtained for compounds 2 . The presence of two acceptor moieties, inducing higher symmetry, gives rise to two virtual orbitals (LUMO and LUMO +1) that are close in energy, and therefore, the lowest energy absorption band encompasses two electronic excitations from HOMO to LUMO and from HOMO to LUMO+1 respectively.

Taking compound 2a as model compound, DFT calculations predict the lowest energy absorption at $509 \mathrm{~nm}$ with 0.48 as oscillator strength (f) (Fig. 7). This absorption is mainly contributed (94\%) from a HOMO to LUMO one electron transition and overlaps to a more intense absorption at $499 \mathrm{~nm}(f=1.30)$ mainly contributed $(94 \%)$ from a HOMO to LUMO+1 transition. 


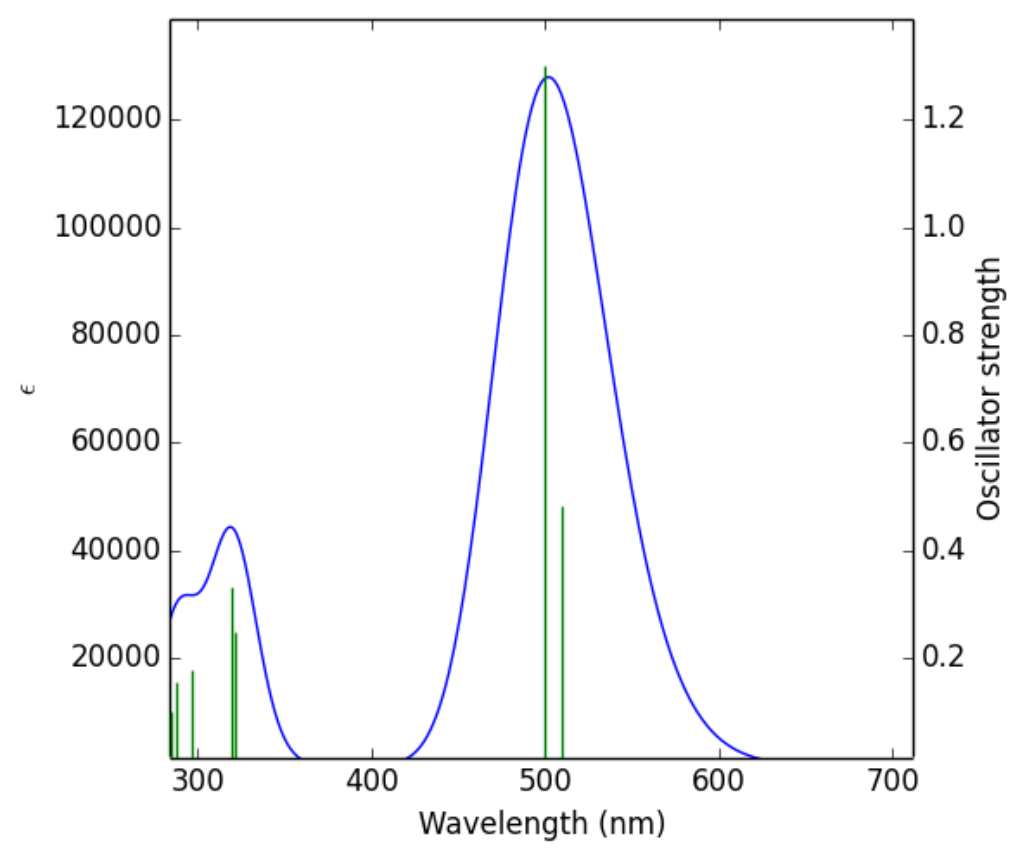

Fig. 7. Calculated UV-vis spectrum for compound $2 \mathbf{a}$ in $\mathrm{CH}_{2} \mathrm{Cl}_{2}$.

\subsection{Electronic properties of thin-films and photovoltaic properties}

Thin-films on glass or indium tin oxide (ITO) substrates were prepared by spin-casting solutions of titled molecules in chloroform and then analyzed by UV-vis spectroscopy and photoelectron spectroscopy in air (PESA), respectively.

The absorption maxima of the ICT band for thin-films of $\mathbf{1 a}, \mathbf{1 b}, \mathbf{2 a}$ and $\mathbf{2 b}$ are observed at $549 \mathrm{~nm}, 646 \mathrm{~nm}, 551 \mathrm{~nm}$ and $646 \mathrm{~nm}$, respectively (Fig. 8). Surprisingly, the passage from the solution to the solid state leads to different behaviors. Whereas a bathochromic shift of 20 $\mathbf{n m}$ is observed for thin-films of $\mathbf{2} \mathbf{b}$ and the optical properties of thin-films of $\mathbf{1 b}$ and $\mathbf{2 a}$ are weakly affected, thin-films of compound 1a are subjected to a hypsochromic shift of $13 \mathrm{~nm}$ compared to solution. In addition, contrary to solutions, there is nearly no difference of absorption maximum of the ICT band between derivatives $\mathbf{1}$ and $\mathbf{2}$ suggesting that the impact of the symmetry of molecules $\mathbf{2}$ on the optical properties in the solid state is really weak. The determination of the onset of absorption at low energy of thin-films of $\mathbf{1 a}, \mathbf{1 b}, \mathbf{2} \mathbf{a}$ and $\mathbf{2} \mathbf{b}$ gives 
an estimation of the optical bandgap $E_{\mathrm{g}}{ }^{\mathrm{opt}}$ of $1.86 \mathrm{eV}, 1.49 \mathrm{eV}, 1.84 \mathrm{eV}$ and $1.51 \mathrm{eV}$, respectively.

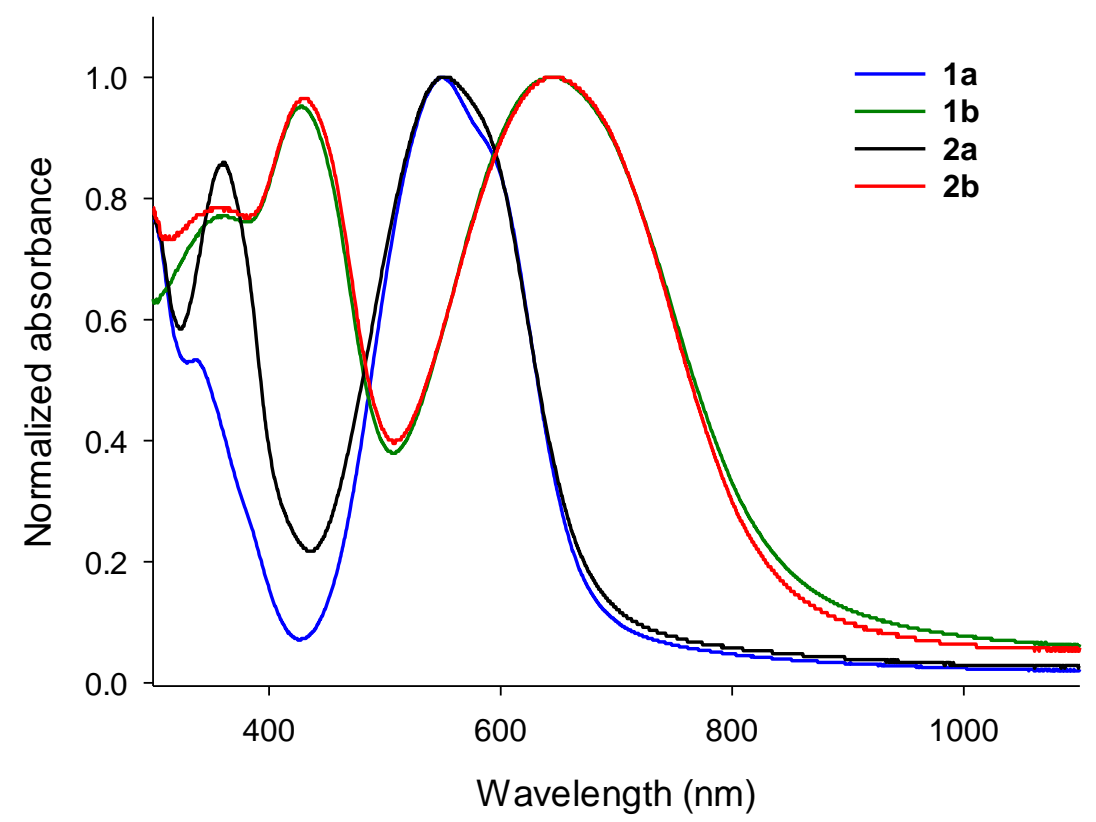

Fig. 8. Normalized UV-vis spectra of spin-casted thin-films on glass.

PESA experiments allowed us to estimate the ionization potentials, assimilated to HOMO levels, giving values of $-5.48 \mathrm{eV},-5.21 \mathrm{eV},-5.73 \mathrm{eV}$ and $-5.30 \mathrm{eV}$ respectively for thinfilms of 1a, 1b, 2a and $\mathbf{2 b}$ (see SI). These values determined in the solid state follow the trend observed by $\mathrm{CV}$ in solution and theoretical calculations. In agreement with its highest positive oxidation potential $\left(E_{\mathrm{ox} 1}{ }^{1 / 2}=+0.88 \mathrm{~V}\right.$ vs $\left.\mathrm{Ag} / \mathrm{AgCl}\right)$, the deepest HOMO level for the series has been measured for compound 2a. However, the passage from 1a to 2a leads to a more pronounced stabilization of the HOMO level in the solid that in the case of $\mathbf{1 b}$ and $\mathbf{2} \mathbf{b}$; the origin of this effect is not yet understood but is probably related to the molecular organization in the thin-films. Fig. 9 shows the energetic diagram with the HOMO and LUMO levels for each compound in the solid state, the LUMO level being estimated using the following equation LUMO $=\mathrm{HOMO}+E_{\mathrm{g}}$ opt . Again, the relative positions of the LUMO levels of 
compounds $\mathbf{1 a}, \mathbf{1 b}$ and $\mathbf{2} \mathbf{b}$ in the solid state are consistent with $\mathrm{CV}$ data and theoretical calculations. On the other hand, due to the very deep HOMO level of $\mathbf{2 a}$, its LUMO level becomes the more stabilized. The energetic diagram shows that all molecules exhibit higher LUMO energy levels than that of $\mathrm{C}_{60}$, which is favorable for photo-induced electron transfer from the titled molecules to $\mathrm{C}_{60}$.

Molecule 2a presents the highest $\mathrm{HOMO}$ (donor)-LUMO $\left(\mathrm{C}_{60}\right)$ difference which is expected to give rise to a high open-circuit voltage $\left(V_{\mathrm{oc}}\right)$ for the corresponding OSCs.

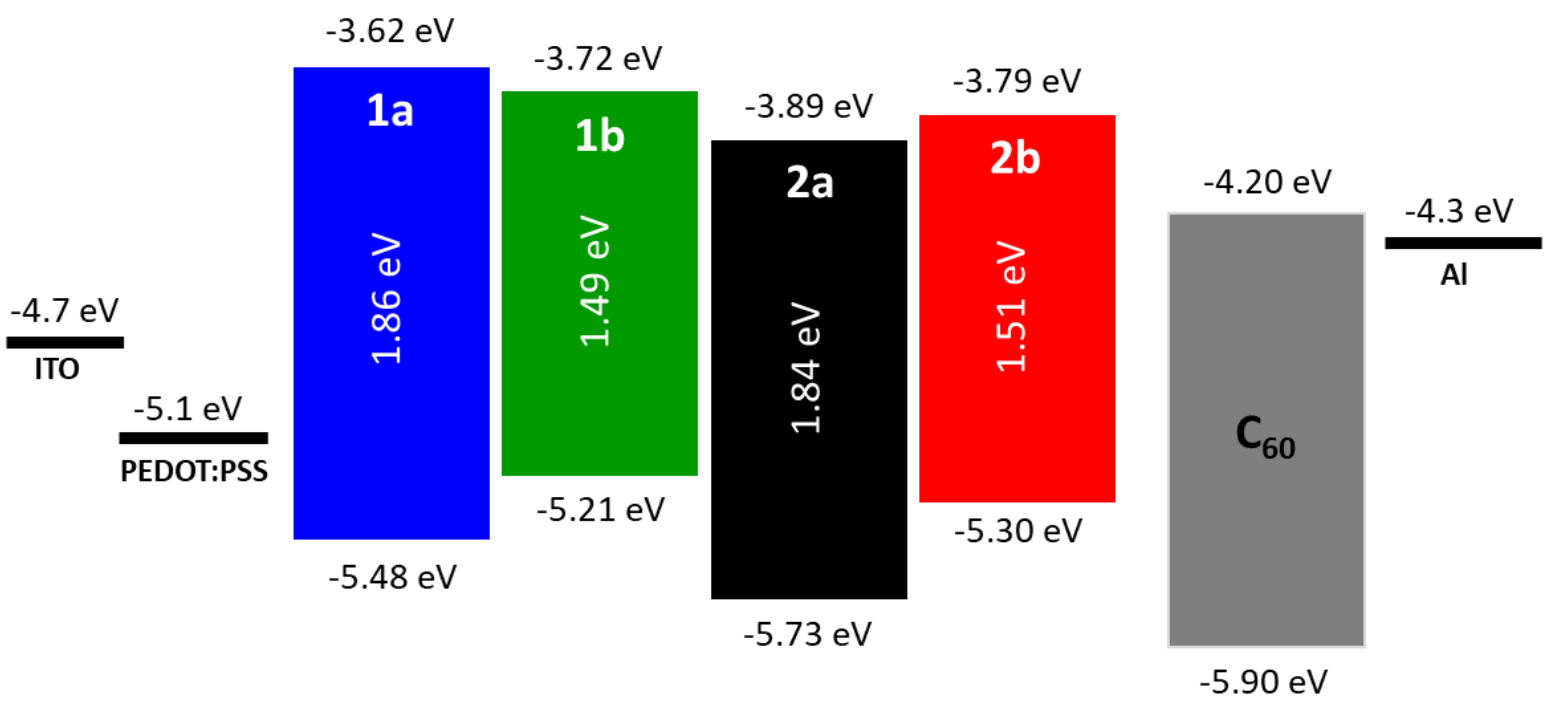

Fig. 9. Energy levels of titled compounds determined in the solid-state by UV-vis spectroscopy and PESA.

Investigations of the photovoltaic performance of the four molecules as donor material were carried out in planar bilayer OSCs with $\mathrm{C}_{60}$ as acceptor. The structure of the bilayer OSCs is as follows: ITO/PEDOT:PSS/Donor/C $60 / \mathrm{Al}$. More details on the fabrication of the devices can be found in the experimental part. A thermal treatment of the bilayer OSCs at $100{ }^{\circ} \mathrm{C}$ for 10 min systematically led to improved performance. The photovoltaic characteristics of the best bilayer OSCs made from the four pyranylidene derivatives are gathered in Table 3. 
Table 3. Photovoltaic parameters of bilayer OSCs with titled donors and $\mathrm{C}_{60}$ under AM1.5 conditions $\left(100 \mathrm{~mW} / \mathrm{cm}^{2}\right){ }^{\mathrm{a}}$

\begin{tabular}{|c|c|c|c|c|}
\hline Donor & $V_{\mathrm{oc}}(\mathrm{V})$ & $J_{\mathrm{sc}}\left(\mathrm{mA} / \mathrm{cm}^{2}\right)$ & $F F(\%)$ & $P C E(\%)$ \\
\hline $\mathbf{1 a}^{\mathrm{b}}$ & 0.28 & 0.21 & 22 & 0.01 \\
\hline $\mathbf{1 b}^{\mathrm{b}}$ & 0.36 & 0.90 & 21 & 0.07 \\
\hline $\mathbf{2 a}^{\mathrm{c}}$ & 0.57 & 1.69 & 34 & 0.33 \\
\hline $\mathbf{2 b}^{\mathrm{b}}$ & 0.39 & 1.54 & 28 & 0.17 \\
\hline
\end{tabular}

${ }^{\mathrm{a}}$ After thermal annealing at $100{ }^{\circ} \mathrm{C}$ for $10 \mathrm{~min} .{ }^{\mathrm{b}}$ Speed rate for deposition of the donor: $6000 \mathrm{rpm}, \mathrm{C}_{60}$ thickness: $25 \mathrm{~nm} .{ }^{\mathrm{c}}$ Speed rate for deposition of the donor: $4000 \mathrm{rpm}, \mathrm{C}_{60}$ thickness: $30 \mathrm{~nm}$.

Table 3 shows that all titled molecules exhibit photovoltaic properties when used as electron-donor material in bilayer OSCs. However, although these molecules exhibit good absorption properties in the visible spectrum and LUMO levels higher than the one of $\mathrm{C}_{60}(\mathrm{ca}$. $-4.2 \mathrm{eV}$ ), as expected for photo-induced electron transfer, their performance are relatively poor. Our data suggest also that symmetrical extended molecules (2a and 2b) show slightly better photovoltaic performance. The best ones were obtained with the symmetrical compound 2a leading to a power conversion efficiency $(P C E)$ of $0.33 \%$ associated with an open-circuit voltage $\left(V_{\mathrm{oc}}\right)$ of $0.57 \mathrm{~V}$, a short-circuit current density $\left(J_{\mathrm{sc}}\right)$ of $1.69 \mathrm{~mA} / \mathrm{cm}^{2}$ and a fill factor $(F F)$ of $34 \%$. The current density vs voltage curves of the best devices for all compounds recorded under illumination are presented in Fig. 10. Interestingly, compound 2a leads to the highest $V_{\mathrm{oc}}$ value in agreement with its deepest HOMO level and the largest LUMO $\left(\mathrm{C}_{60}\right)$-HOMO (Donor) difference. On the other hand, the PV performance of compound 1a are negligible which is consistent with the absence of $\pi-\pi$ intermolecular interactions in its crystal structure, hence probably preventing hole transport that is needed after exciton dissociation at the donor/acceptor interface. In the case of $\mathbf{1 b}, \mathbf{2} \mathbf{a}$ and $\mathbf{2} \mathbf{b}$ showing better PV performance, the more extended $\pi$-conjugated systems may participate to the development of $\pi-\pi$ intermolecular interactions. 


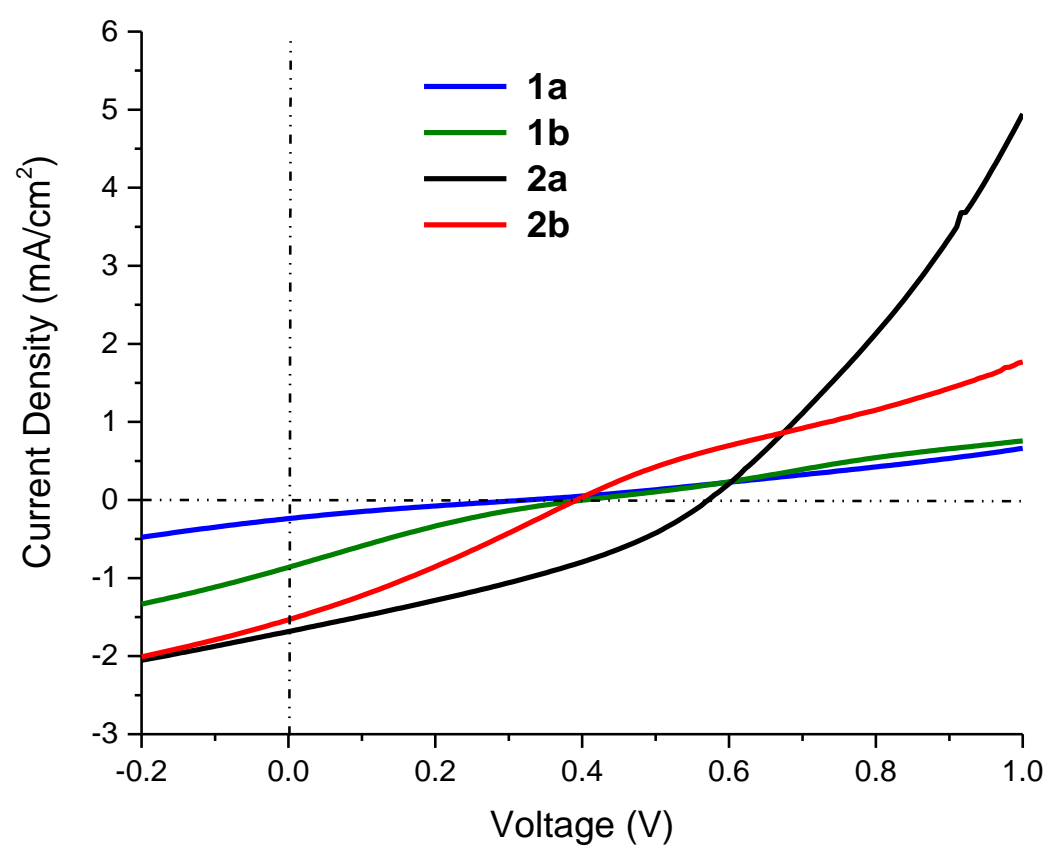

Fig. 10. Current density vs voltage curves of the best bilayer OSC after thermal treatment at $100{ }^{\circ} \mathrm{C}$ for $10 \mathrm{~min}$, under white light at $100 \mathrm{~mW} / \mathrm{cm}^{2}$.

\section{Experimental section}

\subsection{General experimental methods}

See Supporting Information.

\subsection{Device preparation and characterization}

See Supporting Information.

\subsection{Computational details}

See Supporting Information.

\subsection{Starting materials}

Aldehydes 1-CHO[9e] and 2-CHO[9e] and acceptor 4[18] was prepared as previously described.

\subsection{Synthesis and characterizations}


((5-((2,6-di-tert-butyl-4H-pyran-4-ylidene)(thiophen-2-yl)methyl)thiophen-2

\section{yl)methylene)malononitrile (1a)}

A mixture of aldehyde 1-CHO (95.5 mg; $0.24 \mathrm{mmol})$, malononitrile $(33.2 \mathrm{mg} ; 0.50 \mathrm{mmol})$ and basic alumina $(125 \mathrm{mg})$ in anhydrous toluene $(2.8 \mathrm{~mL})$ was refluxed under argon with exclusion of light for one hour (TLC monitoring). Then, the solvent was removed and the residue was purified by flash chromatography (silica gel), using $\mathrm{CH}_{2} \mathrm{Cl}_{2} /$ hexane 6:4 as eluent to give a crystalline violet solid $(88.4 \mathrm{mg} ; 83 \%)$.

Mp $\left({ }^{\circ} \mathrm{C}\right)$ 165-168. IR (KBr): v $\left(\mathrm{cm}^{-1}\right) 3070\left(\mathrm{Csp}^{2}-\mathrm{H}\right), 2971\left(\mathrm{Csp}^{3}-\mathrm{H}\right), 2213(\mathrm{C} \equiv \mathrm{N}), 1658$, 1562 and $1534(\mathrm{C}=\mathrm{C}) .{ }^{1} \mathrm{H}-\mathrm{NMR}\left(400 \mathrm{MHz}, \mathrm{CD}_{2} \mathrm{Cl}_{2}\right): \delta(\mathrm{ppm}) 1.14(\mathrm{~s}, 9 \mathrm{H}), 1.29(\mathrm{~s}, 9 \mathrm{H})$, $5.90(\mathrm{~d}, J=2.2 \mathrm{~Hz}, 1 \mathrm{H}), 6.83(\mathrm{~d}, J=4.3 \mathrm{~Hz}, 1 \mathrm{H}), 6.86(\mathrm{~d}, J=2.2,1 \mathrm{H}), 6.92\left(\mathrm{dd}, J_{1}=3.5\right.$ $\left.\mathrm{Hz}, J_{2}=1.2 \mathrm{~Hz}, 1 \mathrm{H}\right), 7.10\left(\mathrm{dd}, J_{1}=5.2 \mathrm{~Hz}, J_{2}=3.5 \mathrm{~Hz}, 1 \mathrm{H}\right), 7.41\left(\mathrm{dd}, J_{1}=5.2 \mathrm{~Hz}, J_{2}=1.2\right.$ $\mathrm{Hz}, 1 \mathrm{H}), 7.53(\mathrm{~d}, J=4.4 \mathrm{~Hz}, 1 \mathrm{H}), 7.66(\mathrm{~d}, J=0.4 \mathrm{~Hz}, 1 \mathrm{H}) .{ }^{13} \mathrm{C}-\mathrm{NMR}\left(100 \mathrm{MHz}, \mathrm{CD}_{2} \mathrm{Cl}_{2}\right)$ : $\delta(\mathrm{ppm}) 28.0,28.2,36.4,36.7,72.2,101.8,103.8107 .3,115.2,116.1,126.9,127.3,127.9$, 128.9, 132.1, 137.6, 140.0, 142.8, 149.9, 159.6, 167.0, 168.6. HRMS $\left(\mathrm{ESI}^{+}\right) \mathrm{m} / \mathrm{z} 446.1478$ $[\mathrm{M}]^{+\cdot}$ (calculated for $\mathrm{C}_{26} \mathrm{H}_{26} \mathrm{~N}_{2} \mathrm{OS}_{2}$ : 446.1481); $\mathrm{m} / \mathrm{z}, 469.1390 \quad[\mathrm{M}+\mathrm{Na}]^{+}$(calculated for $\left.\mathrm{C}_{26} \mathrm{H}_{26} \mathrm{~N}_{2} \mathrm{NaOS}_{2}: 469.1379\right)$

\section{5-((5-((2,6-di-tert-butyl-4H-pyran-4-ylidene)(thiophen-2-yl)methyl)thiophen-2-} yl)methylene)-2-oxo-4-phenyl-2,5-dihydrofuran-3-carbonitrile (1b)

Compound 4 (48.3 mg; $0.26 \mathrm{mmol}$ ) was added to a solution of aldehyde 1-CHO (93.13 mg, $0.23 \mathrm{mmol})$ in absolute ethanol $(5.5 \mathrm{~mL})$. The mixture was refluxed under argon with exclusion of light for 48 hours (TLC monitoring). After cooling, the resulting solid was filtered, washed with cold hexane, cold ethanol and finally with a cold mixture of pentane $/ \mathrm{CH}_{2} \mathrm{Cl}_{2}$ 9.5:0.5. A dark green solid was collected (112 mg; 86\%).

$\mathrm{Mp}\left({ }^{\circ} \mathrm{C}\right)$ 160-162. IR (KBr): $v\left(\mathrm{~cm}^{-1}\right) 3038\left(\mathrm{Csp}^{2}-\mathrm{H}\right), 2967\left(\mathrm{Csp}^{3}-\mathrm{H}\right), 2219(\mathrm{C} \equiv \mathrm{N}), 1744$ $(\mathrm{C}=\mathrm{O}), 1651,1597$ and 1533 (C=C Ar.). ${ }^{1} \mathrm{H}-\mathrm{NMR}\left(400 \mathrm{MHz}, \mathrm{CD}_{2} \mathrm{Cl}_{2}\right): \delta(\mathrm{ppm}) 1.12(\mathrm{~s}, 9 \mathrm{H})$, 
$1.25(\mathrm{~s}, 9 \mathrm{H}), 5.91(\mathrm{~d}, J=2.2 \mathrm{~Hz}, 1 \mathrm{H}), 6.70(\mathrm{~d}, J=2.2 \mathrm{~Hz}, 1 \mathrm{H}), 6.71(\mathrm{br} \mathrm{s}, 1 \mathrm{H}), 6.90(\mathrm{~d}, J=$ $4.2 \mathrm{~Hz}, 1 \mathrm{H}), 6.92\left(\mathrm{dd}, J_{1}=3.4 \mathrm{~Hz}, J_{2}=1.3 \mathrm{~Hz}, 1 \mathrm{H}\right), 7.0\left(\mathrm{dd}, J_{1}=5.2 \mathrm{~Hz}, J_{2}=3.4 \mathrm{~Hz}, 1 \mathrm{H}\right)$, $7.37\left(\mathrm{dd}, J_{1}=5.2 \mathrm{~Hz}, J_{2}=1.2 \mathrm{~Hz}, 1 \mathrm{H}\right), 7.39(\mathrm{~d}, J=4.2 \mathrm{~Hz}, 1 \mathrm{H}), 7.63-7.61(\mathrm{~m}, 5 \mathrm{H}) .{ }^{13} \mathrm{C}-$ NMR (100 MHz, $\mathrm{CD}_{2} \mathrm{Cl}_{2}$ ): $\delta(\mathrm{ppm})$ 28.1, 28.2, 36.3, 36.5, 93.8, 101.7, 103.2, 113.2, 116.0, $126.6,127.2,128.7,129.4,130.0,132.4,134.0,135.4,136.8,143.6,161.6,166.1,167.3$. HRMS (ESI ${ }^{+}$): $m / \mathrm{z} 565.1719[\mathrm{M}]^{+\cdot}$ (calculated for $\left.\mathrm{C}_{34} \mathrm{H}_{11} \mathrm{NO}_{3} \mathrm{~S}_{2}: 565.1740\right)$.

\section{((((2,6-di-tert-butyl-4H-pyran-4-ylidene)methylene)bis(thiophene-5,2-}

\section{diyl))bis(methanylylidene))dimalononitrile (2a)}

A mixture of aldehyde 2-CHO (105 mg; $0.25 \mathrm{mmol})$, malononitrile $(66 \mathrm{mg} ; 1.00 \mathrm{mmol})$ and basic alumina $(250 \mathrm{mg})$ in anhydrous toluene $(4 \mathrm{~mL})$ was heated at reflux under argon with exclusion of light for 48 hours (TLC monitoring). Then, the solvent was evaporated under vacuum and the crude product was purified by flash chromatography on silica gel, using $\mathrm{CH}_{2} \mathrm{Cl}_{2} /$ hexane 9:1 as eluent to afford a maroon solid (33.9 mg; 26\%).

$\mathrm{Mp}\left({ }^{\circ} \mathrm{C}\right)$ 206-207. IR ( $\left.\mathrm{KBr}\right): v\left(\mathrm{~cm}^{-1}\right) 2958\left(\mathrm{Csp}^{3}-\mathrm{H}\right), 2218(\mathrm{C} \equiv \mathrm{N}), 1659,1571$ and 1530 $\left(\mathrm{C}=\mathrm{C}\right.$ Ar.). ${ }^{1} \mathrm{H}-\mathrm{NMR}\left(400 \mathrm{MHz}, \mathrm{CD}_{2} \mathrm{Cl}_{2}\right): \delta(\mathrm{ppm}) 1.23(\mathrm{~s}, 9 \mathrm{H}), 6.46(\mathrm{~s}, 1 \mathrm{H}), 7.00(\mathrm{~d}, J=4.1$ $\mathrm{Hz}, 1 \mathrm{H}), 7.66\left(\mathrm{dd}, J_{1}=4.2 \mathrm{~Hz}, J_{2}=0.4 \mathrm{~Hz}, 1 \mathrm{H}\right), 7.78($ br s, $1 \mathrm{H}) .{ }^{13} \mathrm{C}-\mathrm{NMR}(100 \mathrm{MHz}$, $\left.\mathrm{CD}_{2} \mathrm{Cl}_{2}\right): \delta(\mathrm{ppm}) 27.9,30.1,75.6,102.7,105.4,114.3,115.1,129.2,134.2,138.9,139.9$, 150.5, 156.7, 168.9. HRMS $\left(\mathrm{ESI}^{+}\right.$): $\mathrm{m} / z, 523.1599[\mathrm{M}+\mathrm{H}]^{+}$(calculated for $\mathrm{C}_{30} \mathrm{H}_{27} \mathrm{~N}_{4} \mathrm{OS}_{2}$ : 523.1621); $m / z$ 545.1432 [M+Na $]^{+}$(calculated for $\mathrm{C}_{30} \mathrm{H}_{26} \mathrm{~N}_{4} \mathrm{NaOS}_{2}: 545.1440$ ).

\section{5,5'-((((2,6-di-tert-butyl-4H-pyran-4-ylidene)methylene)bis(thiophene-5,2-}

\section{diyl))bis(methanylylidene))bis(2-oxo-4-phenyl-2,5-dihydrofuran-3-carbonitrile) (2b)}

Compound 4 (84.7 mg; $0.44 \mathrm{mmol}$ ) was added to a solution of aldehyde 2-CHO (84.6 mg, $0.20 \mathrm{mmol})$ in absolute ethanol $(5 \mathrm{~mL})$. The mixture was refluxed under argon with exclusion of light for 3 days (TLC monitoring). After cooling, the resulting solid was isolated by 
filtration, washed with cold pentane, cold ethanol and finally with a cold mixture of pentane $/ \mathrm{CH}_{2} \mathrm{Cl}_{2}$ 9:1. A dark green solid was obtained (109 mg; 72\%).

Mp $\left({ }^{\circ} \mathrm{C}\right) 215$ (dec.). IR (KBr): $v\left(\mathrm{~cm}^{-1}\right) 3064\left(\mathrm{Csp}^{2}-\mathrm{H}\right), 2964\left(\mathrm{Csp}^{3}-\mathrm{H}\right), 2224(\mathrm{C} \equiv \mathrm{N}), 1761$ $(\mathrm{C}=\mathrm{O}), 1655,1613$ and $1553(\mathrm{C}=\mathrm{C}$ Ar. $) .{ }^{1} \mathrm{H}-\mathrm{NMR}\left(400 \mathrm{MHz}, \mathrm{CD}_{2} \mathrm{Cl}_{2}\right): \delta(\mathrm{ppm}) 1.22(\mathrm{~s}, 9 \mathrm{H})$, $6.40(\mathrm{~s}, 1 \mathrm{H}), 6.79(\mathrm{~s}, 1 \mathrm{H}), 7.05(\mathrm{~d}, J=4.0 \mathrm{~Hz}, 1 \mathrm{H}), 7.46(\mathrm{~d}, J=4.0 \mathrm{~Hz}, 1 \mathrm{H}), 7.65-7.64(\mathrm{~m}$,

$5 \mathrm{H}) .{ }^{13} \mathrm{C}-\mathrm{NMR}\left(100 \mathrm{MHz}, \mathrm{CD}_{2} \mathrm{Cl}_{2}\right): \delta(\mathrm{ppm})$ 28.1, 36.5, 97.1, 102.8, 107.0, 112.9, 115.6, $128.4,129.2,129.4,130.1,132.6,135.7,136.5,136.6,143.7,155.8,162.3,164.7,167.7$. HRMS (ESI ${ }^{+}$): $m / z, 783.1960[\mathrm{M}+\mathrm{Na}]^{+}$(calculated for $\mathrm{C}_{46} \mathrm{H}_{36} \mathrm{~N}_{2} \mathrm{NaO}_{5} \mathrm{~S}_{2}: 783.1958$ ).

\section{Conclusions}

Four new push-pull systems containing a $4 H$-pyranylidene moiety as electron-donating block have been designed and synthesized: V-shaped chromophores 2 present a blue-shifted absorption in solution and higher $E_{\mathrm{ox}}$ values compared to their linear analogues 1 . On the other hand, furanone derivatives $\mathbf{b}$ show a lower electrochemical gap and higher $\lambda_{\max }$ and $\varepsilon$ values than for their analogues a with the DCV moiety. The analysis of the crystalline structure of compound 1a by X-ray diffraction has revealed the absence of strong intermolecular interactions due to a thienyl unit out of the plane of the push-pull conjugated segment.

Thin-film of the four molecules have been analyzed by UV-vis spectroscopy and PESA allowing us to draw the corresponding energetic diagram suggesting a potential interest in OPV. The four small molecules have been then evaluated as donor materials in bilayer OSCs in combination with $\mathrm{C}_{60}$. Our preliminary results show a clear photovoltaic effect, however with low power conversion efficiencies. The best $P C E$ value of $0.33 \%$ was obtained for a bilayer OSC based on $\mathbf{2 a}$, associated to low $J_{\mathrm{sc}}$ and $F F$ values, $1.69 \mathrm{~mA} / \mathrm{cm}^{2}$ and $34 \%$ 
respectively. These results suggest limited hole transport properties for $\mathbf{2 a}$ as well as for the other titled compounds due to weak $\pi-\pi$ intermolecular interactions.

Acknowledgments. Financial support from MINECO (CTQ2014-52331R), Gobierno de Aragón-FEDER-Fondo Social Europeo 2014-2020 (E14_17R) and University of Zaragoza (UZ2019-CIE-01) is gratefully acknowledged. The plateau CARMA of the SFR Matrix is acknowledged for the fabrication and characterization of organic solar cells. Martin Blais thanks the University of Angers for his contract as Engineer.

\section{References}

[1] a) Roncali, J. Molecular Bulk Heterojunctions: An Emerging Approach to Organic Solar Cells. Acc Chem Res 2009;42:1719-30; b) Würthner F, Meerholz K. Systems Chemistry Approach in Organic Photovoltaics. Chem Eur J 2010;16:9366-73; c) Li, Y, Guo Q, Li Z, Pei J, Tian W. Solution processable D-A small molecules for bulk-heterojunction solar cells. Energy Environ Sci 2010;3:1427-36; d) Walker B, Kim C, Nguyen T-Q. Small Molecule Solution-Processed Bulk Heterojunction Solar Cells. Chem Mater 2011;23:470-82; e) Lin Y, Li Y, Zhan X. Small molecule semiconductors for high-efficiency organic photovoltaics. Chem Soc Rev 2012;41:4245-72; f) Mishra A, Bäuerle P. Small Molecule Organic Semiconductors on the Move: Promises for Future Solar Energy Technology. Angew Chem Int Ed 2012;51:2020-37.

[2] a) McAfee SM, Topple JM, Hill IG, Welch GC. Key components to the recent performance increases of solution processed non-fullerene small molecule acceptors. J Mater Chem A 2015;3:16393-408; b) Li W, Yao H, Zhang H, Li S, Hou J. Potential of Nonfullerene Small Molecules with High Photovoltaic Performance. Chem Asian J 2017;12:2160-71; c) Li S, Zhang Z, Shi M, Li C-Z, Chen H. Molecular electron acceptors for efficient fullerene-free 
organic solar cells. Phys Chem Chem Phys 2017;19:3440-58; d) Chen W, Zhang Q. Recent progress in non-fullerene small molecule acceptors in organic solar cells (OSCs). J Mater Chem C 2017;5:1275-1302; e) Zhan J, Tan HS, Guo X, Facchetti A, Yan H. Material insights and challenges for non-fullerene organic solar cells based on small molecular acceptors. Nat Energy 2018;3:720-31.

[3] a) Roncali J, Leriche P, Blanchard P. Molecular Materials for Organic Photovoltaics: Small is Beautiful. Adv Mater 2014;26:3821-38; b) Malytskyi V, Simon J-J, Patrone L, Raimundo J-M. Thiophene-based push-pull chromophores for small molecule organic solar cells (SMOSCs). RSC Adv 2015;5:354-97; c) Wang J, Liu K, Ma L, Zhan X. Triarylamine: Versatile Platform for Organic, Dye-Sensitized, and Perovskite Solar Cells. Chem Rev 2016;116:14675-725; d) Blanchard P, Malacrida C, Cabanetos C, Roncali J, Ludwigs S. Triphenylamine and some of its derivatives as versatile building blocks for organic electronic applications. Polym Int 2019;68:589-606; e) Cabanetos C, Blanchard P, Roncali J. Arylamine Based Photoactive Push-Pull Molecular Systems: A Brief Overview of the Chemistry "Made in Angers". Chem Rec 2019;19:1123-130.

[4] Andreu R, Carrasquer L, Franco S, Garín J, Orduna J, Martínez de Baroja N et al. 4HPyran-4-ylidenes: strong proaromatic donors for organic nonlinear optical chromophores. J Org Chem 2009;74:6647-57.

[5] a) malononitrile: Yao Y-S, Xiao J, Wang X-S, Deng Z-B, Zhang B-W. Starburst DCMType Red-Light-Emitting Materials for Electroluminescence Applications. Adv Funct Mater 2006;16:709-18; b) dicyanovinylindan-3-one: Maglione C, Carella A, Carbonara C, Centore R, Fusco S, Velardo A et al. Novel pyran based dyes for application in dye sensitized solar cells. Dyes Pigm 2016;133:395-405; c) indanedione, thiobarbituric acid: Kim DU, Paik S-H, Kim S-H, Tak Y-H, Han Y-S, Kim S-D et al. Electro-optical characteristics of indandione- 
pyran derivatives as red emission dopants in electroluminescent device. Mater Sci Eng C 2004;24:147-9.

[6] Selected examples for 4H-pyranylidene-containing chromophores: a) Andreu R, Galán E, Orduna J, Villacampa B, Alicante R, López Navarrete JT et al. Aromatic/proaromatic donors in 2-dicyanomethylenethiazole merocyanines: from neutral to strongly zwitterionic nonlinear optical chromophores. Chem Eur J 2011;17:826-38; b) Galán E, Andreu R, Garín J, Orduna J, Villacampa B, Diosdado BE. Cycloaddition reactions of polyenic Donor- $\pi$-Acceptor systems with an electron-rich alkyne: access to new chromophores with second-order optical nonlinearities. Org Biomol Chem 2012;10:8684-91; c) Achelle S, Malval J-P, Aloïse S, Barsella A, Spangenberg A, Mager L et al. Synthesis, photophysics and nonlinear optical properties of stilbenoid pyrimidine-based dyes bearing methylenepyran donor groups. ChemPhysChem 2013;14:2725-36; d) Marco AB, Martínez de Baroja N, Franco S, Garín J, Orduna J, Villacampa B et al. Dithienopyrrole as a rigid alternative to the bithiophene $\pi$-relay in chromophores with second-order nonlinear optical properties. Chem Asian J 2015;10:188-97; e) Durand RJ, Gauthier S, Achelle S, Groizard T, Kahlal S, Saillard J-Y et al. Push-pull D- $\pi-R u-\pi-A$ chromophores: synthesis and electrochemical, photophysical and second order nonlinear optical properties. Dalton Trans 2018;47:3965-75.

[7] a) Ambrosio A, Orabona E, Maddalena P, Camposeo A, Polo M, Neves AAR et al. Twophoton patterning of a polymer containing Y-shaped azochromophores. Appl Phys Lett 2009;94:011115; b) Ambrosio A, Maddalena P, Carella A, Borbone F, Roviello A, Polo M, et al. Two-Photon induced self-structuring of polymeric films based on Y-shape azobenzene chromophore. J Phys Chem C 2011;28:13566-70; c) Poronik YM, Hugues V, BlanchardDesce M, Gryko DT. Octupolar merocyanine dyes: a new class of nonlinear optical chromophores. Chem Eur J 2012;18:9258-66. 
[8] a) Yang Y, Peng T, Ye K, Wu Y, Liu Y, Wang Y. High-efficiency and high-quality white organic light-emitting diode employing fluorescent emitters. Org Electron 2011;12:29-33; b) Guo Z, Zhu W, Tian H. Dicyanomethylene-4H-pyran chromophores for OLED emitters, logic gates and optical chemosensors. Chem Commun 2012;48:6073-84.

[9] Selected examples: a) Bolag A, Nishida J-i, Hara K, Yamashita Y. Dye-sensitized solar cells based on novel diphenylpyran derivatives. Chem Lett 2011;40:510-1; b) Franco S, Garín J, Martínez de Baroja N, Pérez-Tejada R, Orduna J, Yu Y et al. New D- $\pi$-A-conjugated organic sensitizers based on 4H-pyran-4-ylidene donors for highly efficient dye-sensitized solar cells. Org Lett 2012;14:752-5; c) Marco AB, Martínez de Baroja N, Andrés-Castán JM, Franco S, Andreu R, Villacampa B et al. Pyranylidene/thienothiophene-based organic sensitizers for Dye-Sensitized Solar Cells. Dyes Pigm 2019;161:205-13; d) Gauthier S, Robin-Le Guen F, Wojcik L, Le Poul N, Planchat A, Pellegrin Y et al. Synthesis and properties of novel pyranylidene-based organic sensitizers for dye-sensitized solar cells. Dyes Pigm 2019;171:107747; e) Andrés-Castán JM, Andreu R, Villacampa B, Orduna J, Franco S. $4 H$-pyranylidene organic dyes for dye-sensitized solar cells: twisted structures towards enhanced power conversion efficiencies. Sol Energy 2019;193:74-84.

[10] a) Liu Y, Lei Y, Li F, Chen J, Liu M, Huang X et al. Indene-1,3-dionemethylene-4Hpyran derivatives containing alkoxy chains of various lengths: aggregation-induced emission enhancement, mechanofluorochromic properties and solvent-induced emission changes. $\mathbf{J}$ Mater Chem C 2016;4:2862-70; b) Cao Y, Chen L, Xi Y, Li Y, Yan X. Stimuli-responsive 2,6-diarylethene- $4 H$-pyran-4-one derivatives: Aggregation induced emission enhancement, mechanochromism and solvatochromism. Materials Lett 2018;212:225-30.

[11] See for example: a) He C, He Q, Yang X, Wu G, Yang C, Bai F et al. Synthesis and Photovoltaic Properties of a Solution-Processable Organic Molecule Containing Triphenylamine and DCM Moieties. J Phys Chem C 2007;111:8661-6; b) Zhao G, Wu G, He 
C, Bai F-Q, Xi H, Zhang H-X et al. Solution-Processable Multiarmed Organic Molecules Containing Triphenylamine and DCM Moieties: Synthesis and Photovoltaic Properties. J Phys Chem C 2009;113:2636-42; c) Li Z, Dong Q, Li Y, Xu B, Deng M, Pei J et al. Design and synthesis of solution processable small molecules towards high photovoltaic performance. J Mater Chem 2011;21:2159-68; d) Zhang J, Wu G, He C, Deng D, Li Y. Triphenylamine-containing D-A-D molecules with (dicyanomethylene)pyran as an acceptor unit for bulk-heterojunction organic solar cells. J Mater Chem 2011;21:3768-74; e) Li Z, Dong Q, Xu B, Li H, Wen S, Pei J et al. New amorphous small molecules-Synthesis, characterization and their application in bulk heterojunction solar cells. Sol Energy Mater Sol Cells 2011;95:2272-80; f) Li Z, Bian J, Wang Y, Jiang F, Liang G, He P et al. Effect of alkyl chain length on the photovoltaic performance of oligothiophene-based small molecules. Sol Energy Mater Sol Cells 2014;130:336-46.

[12] a) Siram RBK, Tandy K, Horecha M, Formanek P, Stamm M, Gevorgyan S et al. Synthesis and Self-Assembly of Donor-Acceptor-Donor Based Oligothiophenes and Their Optoelectronic Properties. J Phys Chem C 2011;115:14369-76; b) Li Z, Dong Q, Xu B, Cheng W, Yao S, Zhang X et al. Novel solution processable small molecule containing new electron-withdrawing group and oligothiophene for photovoltaic. Sol Energy Mater Sol Cells 2012;98:343-50; c) Siram RBK, Stephen M, Ali F, Patil S. Investigation of Phase Separation in Bulk Heterojunction Solar Cells via Supramolecular Chemistry. J Phys Chem C 2013;117:9129-36.

[13] Gräßler N, Wolf S, Holzmüller F, Zeika O, Vandewal K, Leo K. Heteroquinoid Merocyanine Dyes with High Thermal Stability as Absorber Materials in Vacuum-Processed Organic Solar Cells. Eur J Org Chem 2019;845-51.

[14] a) Wen S, Wu Y, Wang Y, Li Y, Liu L, Jiang $\mathrm{H}$ et al. Pyran-Bridged Indacenodithiophene as a Building Block for Constructing Efficient A-D-A-Type 
Nonfullerene Acceptors for Polymer Solar Cells. ChemSusChem 2018;11:360-6; b) Yang L, Li M, Song J, Zhou Y, Bo Z, Wang H. Molecular Consideration for Small Molecular Acceptors Based on Ladder-Type Dipyran: Influences of O-Functionalization and $\pi$-Bridges. Adv Funct Mater 2018;28:1705927-1-11.

[15] Shen C, Courté M, Krishna A, Tang S, Fichou D. Quinoidal 2,2',6,6'-TetraphenylDipyranylidene as a Dopant-Free Hole-Transport Material for Stable and Cost-Effective Perovskite Solar Cells. Energy Technol 2017;5:1852-8.

[16] Courté M, Alaaeddine M, Barth V, Tortech L, Fichou D. Structural and electronic properties of 2,2',6,6'-tetraphenyldipyranylidene and its use as a hole-collecting interfacial layer in organic solar cells. Dyes Pigm 2017;141:487-92.

[17] Moreno-Yruela C, Garín J, Orduna J, Franco S, Quintero E, López Navarrete JT et al. D$\pi$-A compounds with tunable intramolecular charge transfer achieved by incorporation of butenolide nitriles as acceptor moieties. J Org Chem 2015;80:12115-28.

[18] Ford JA Jr, Wilson CV, Young WR. The Preparation of 2(5H)-Furanones and Dyes Derived from Them. J Org Chem 1967;32:173-7.

[19] Lin L-Y, Chen Y-H, Huang Z-Y, Lin H-W, Chou S-H, Lin F et al. A Low-Energy-Gap Organic Dye for High-Performance Small-Molecule Organic Solar Cells. J Am Chem Soc 2011;133:15822-5.

[20] Marco AB, Mayorga Burrezo P, Mosteo L, Franco S, Garín J, Orduna J et al. Polarization, second-order nonlinear optical properties and electrochromism in $4 H$ pyranylidene chromophores with a quinoid/aromatic thiophene ring bridge. RSC Adv 2015;5:231-42.

[21] See for example: a) Moore AJ, Chesney A, Bryce MR, Batsanov AS, Kelly JF, Howard JAK et al. Synthesis, Structures and Nonlinear Optical Properties of Novel D- $\pi$-A Chromophores: Intramolecular Charge Transfer from 1,3-Dithiole or Ferrocene Moieties to 
Polynitrofluorene or Dicyanomethylene Moieties through Conjugated Linkers. Eur J Org Chem 2001;2671-87; b) Fitzner R, Reinold E, Mishra A, Mena-Osteritz E, Ziehkle H, Körner C et al. Dicyanovinyl-Substituted Oligothiophenes: Structure-Property Relationships and Application in Vacuum-Processed Small-Molecule Organic Solar Cells. Adv Funct Mater 2011;21:897-910; c) Leliège A, Grolleau J, Allain M, Blanchard P, Demeter D, Rousseau T et al. Small D- $\pi-$ A Systems with $o$-Phenylene-Bridged Accepting Units as Active Materials for Organic Photovoltaics. Chem Eur J 2013;19:9948-60; d) Baert F, Cabanetos C, Allain M, Silvestre V, Leriche P, Blanchard P. Thieno[2,3-b]indole-Based Small Push-Pull Chromophores: Synthesis, Structure, and Electronic Properties. Org Lett 2016;18:1582-5.

[22] Allen FH, Kennard O, Watson DG, Brammer L, Orpen AG, Taylor R. Tables of Bond Lengths determined by X-Ray and Neutron Diffraction. Part 1. Bond Lengths in Organic Compounds. J Chem Soc Perkin Trans 2 1987;S1-S19.

[23] Chasseau D, Gaultier J, Hauw C, Fugnitto R, Gianis V, Strzelecka H. Tétraphényldipyranylidène (DIP $\left.\mathrm{Ph}_{4}\right)$. Acta Crystallogr, Sect B: Struct Crystallogr Cryst Chem 1982;38:1629-31.

[24] See for example: Marco AB, Andreu R, Franco S, Garín J, Orduna J, Villacampa B et al. Push-pull systems bearing a quinoid/aromatic thieno-[3,2-b]thiophene moiety: synthesis, ground state polarization and second-order nonlinear properties. Org Biomol Chem. $2013 ; 11: 6338-49$.

[25] a) Bürckstümmer H, Tulyakova EV, Deppisch M, Lenze MR, Kronenberg NM, Gsänger M. Efficient Solution-Processed Bulk Heterojunction Solar Cells by Antiparallel Supramolecular Arrangement of Dipolar Donor-Acceptor Dyes. Angew Chem Int Ed 2011;50:11628-32; b) Chiu S-W, Lin L-Y, Lin H-W, Chen Y-H, Huang Z-Y, Lin Y-T et al. A donor-acceptor-acceptor molecule for vacuum-processed organic solar cells with a power conversion efficiency of $6.4 \%$. Chem Commun 2012;48:1857-9; c) Leliège A, Le Régent C- 
H, Allain M, Blanchard P, Roncali J. Structural modulation of internal charge transfer in small molecular donors for organic solar cells. Chem Commun 2012;48:8907-9.

[26] a) Ba F, Cabon N, Le Poul P, Kahlal S, Saillard J-Y, Le Poul N et al. Diferrocenylpyrylium salts and electron rich bispyran from oxidative coupling of ferrocenylpyran. Example of redox systems switched by proton transfer New J Chem 2013;37:2066-81; b) Gauthier S, Vologdin N, Achelle S, Barsella A, Caro B, Robin-le Guen F. Methylenepyran based dipolar and quadrupolar dyes: synthesis, electrochemical and photochemical properties. Tetrahedron 2013;69:8392-9; c) Novoa N, Roisnel T, Dorcet V, Hamond J-R, Carrillo D, Manzur C et al. Anisyl and ferrocenyl adducts of methylenepyrancontaining $\beta$-diketone: Synthesis, spectral, structural, and redox properties. J Organomet Chem 2014;762:19-28; d) Gauthier S, Caro B, Robin-Le Guen F, Bhuvanesh N, Gladysz JA, Wojcik L et al. Synthesis, photovoltaic performances and TD-DFT modeling of push-pull diacetylide platinum complexes in $\mathrm{TiO}_{2}$ based dye-sensitized solar cells. Dalton Trans 2014;43:11233-42; e) Le Poul P, Le Poul N, Golhen S, Robin-Le Guen F, Caro B. The synthesis of flexible tetrapyridylethanes from pyridylpyrylium dications. New J Chem 2016;40:5666-9; f) Wojcik L, Michaud F, Gauthier S, Cabon N, Le Poul P, Gloaguen F et al. Reversible Redox Switching of Chromophoric Phenylmethylenepyrans by Carbon-Carbon Bond Making/Breaking. J Org Chem 2017;82:12395-405; g) Wojcik L, López I, Gauthier S, Cabon N, Le Poul P, Gloaguen F et al. Insights into the radical-radical and radical-substrate dimerization processes for substituted phenylmethylenepyrans. Electrochimica Acta 2019;305:304-11.

[27] a) Durand RJ, Gauthier S, Achelle S, Kahlal S, Saillard J-Y, Barsella A et al. Incorporation of a platinum center in the pi-conjugated core of push-pull chromophores for nonlinear optics (NLO). Dalton Trans 2017;46:3059-69; b) Gauthier S, Porter A, Achelle S, Roisnel T, Dorcet V, Barsella A et al. Mono- and Diplatinum Polyynediyl Complexes as 
Potential Push-Pull Chromophores: Synthesis, Characterization, TD-DFT Modeling, and Photophysical and NLO Properties. Organometallics 2018;37:2232-44. 